\title{
The Role of $\beta$-1,3/1,6-D-Glucan Forms of Polysaccharide Peptide (PsP) from Mycelia Ganoderma lucidum Extracts for Lowering Elevated Total Cholesterol Level in Patients with Heart Failure in Ischaemic Heart Disease
}

\author{
Djanggan Sargowo ${ }^{1 *}$, Titin Andri Wihastuti ${ }^{2}$, Elvira Sari Dewi ${ }^{3}$ and Diana Nanda Saputri ${ }^{4}$ \\ ${ }^{1}$ Centre Study of Degenerative Disease of Brawijaya University General Hospital, Specialist of Cardiology and Vascular \\ Departement, Faculty of Medicine, University of Brawijaya Malang, Indonesia \\ 2 Basic Nursing Departement, Faculty of Medicine, University of Brawijaya Malang, Indonesia \\ 3 Basic Nursing Departement, Faculty of Medicine, University of Brawijaya Malang, Indonesia \\ 4 Nursing Study Program of Faculty of Medicine, University of Brawijaya Malang, Indonesia
}

Submission: October 2020; Revised: October 2020; Accepted: November 2020

*Corresponding author: Djanggan Sargowo; e-mail: djanggan@yahoo.com; tel.: 081330721848

\begin{abstract}
High levels of total cholesterol can worsen the condition of ischemic heart failure. Polysaccharide peptide $(P s P)$ is a capsule of Ganoderma lucidum extract. This study aims to measure changes in total cholesterol levels in patients with ischemic heart failure before and after the PSP and Placebo administration and to analyze differences in decreases in total cholesterol levels between PSP and Placebo group. This research is a true experiment with a prospective double-blind randomized control method through pre-post test design. The sample consisted of 26 patients, divided into 2 groups and given PSP or placebo capsules per oral interventions carried out every day for 90 days. Venipuncture blood was taken before and after the intervention to measure total cholesterol levels by spectrophotometry methods. Paired T Test was used to determine the average reduction in total cholesterol levels for each group. Independent $T$ Test was used to determine the difference of reduction in total cholesterol average between the two groups. The decrease of total cholesterol average level in PsP group was $24.3 \mathrm{mg} / \mathrm{dl}$ ( $p$ value 0.001) and an increase of Placebo group was $8.3 \mathrm{mg} / \mathrm{dl}$ ( $p$ value 0.099). The average reduction in total cholesterol levels in PsP : Placebo group was 24.31: -8.31 mg/dl ( $p$ value 0.000). There was significant decrease total cholesterol levels in PsP group and neither was of the Placebo group. In addition, there was significant difference in the reduction of total cholesterol levels between PSP and Placebo group.
\end{abstract}

Keywords: Ischemic Heart Failure, Total Cholesterol, PsP, Ganoderma lucidum

\section{INTRODUCTION}

Ischemic heart failure is a condition in which the heart could not pump sufficient heart supply to fulfill the metabolism's requirements of body tissue [1]. Heart failure frequently requires re-treatment or periodic care to the hospital due to high cholesterol foods' over-consumption.

The cholesterol content of foods will be absorbed in the small intestine mucosa which then transported to the liver. Here in after, the liver would deliver it to all cell bodies by a lipoprotein called LDL. When cholesterol needs are already fulfilled, cholesterol-riched LDL will be captured by macrophages of vascular endothelium forming foam cells to plaque. Plaque on the blood vessel walls would increase peripheral resistance or increase afterload hence there will be an increase in the workload of the heart [2]. A study that researches about polysaccharide peptide (PsP) in rats as an experimental animal to assess its role as a chronic anti-inflammatory agent and antioxidant agent [3] with notes that it doesn't have toxic effect from giving 5 doses variation. Therefore, it shows that PsP is safe to be consumed [4].
PsP research in a human approves its ability as a chronic anti-inflammatory agent, antioxidant as an antioxidant inhibitor agent, and decrease patient morbidity in NSTEMI and STEMI [3]. That's why researchers are interested in knowing the role of $\beta$ 1,3/1,6-D-Glucan PsP of misellia Ganoderma lucidum extract to lower the increased total cholesterol level in a ischaemic heart failure patient.

\section{METHODS}

\section{Design and Sampling}

This research is a true experimental using double blind prospective randomized controlled trial method with pre-post test control group design. Sampling in this research using patients coming to Cardiovascular Polyclinic of Saiful Anwar General Hospital in Malang whose diagnosed myocardial infarction with ischaemic heart failure especially in a hypercholesterolemia comorbidity of 26 minimum respondents for 2 groups with control.

\section{Time and Place of The Research}

This research is conducted in June-September 2019 in Cardiovascular Polyclinic of Saiful Anwar General Hospital in Malang with the assistance of Lavallete General Hospital, Indonesian Heart 
Foundation, Malang Gerontology Foundation, Biomedical and Physiological Laboratory, and Prodia Laboratory.

\section{Procedures}

After getting the number of samples according to the target, researchers see after the ethical eligibility document. Thus, this research has been approved by Health Research Ethics Commission of Medical Faculty Brawijaya University with document number of 171A/EC/KEPK/07/2018. Respondents who are willing to participate in the research will explain the research goals, benefits of research, and how to fill out a questionnaire.

Then they will be randomly divided into 2 groups, those are PsP capsule given group and the other is placebo capsule given group. All the capsules will be consumed every day for 90 days orally. Before and after the intervention, a venous blood sample of all respondents will be taken (venipuncture) for measuring total cholesterol level using spectrophotometry assay with investigation the presence of resorufin according to the procedure of Prodia Laboratory as a work partner in this research.

\section{RESULTS AND DISCUSSIONS}

According to the result (Table 1), average age of heart failure respondents with hypercholesterolemia is $>60$ years old, in accordance with other research that denoted age range of patients with hypercholesterolemia is 5564 years old [5]. There's a significant reduction in the total cholesteol level of PsP group, according to the previous theory and research in which $\beta$-Glucan of PsP can form a gel on the surface of the intestinal mucosa (Figure 1).

Therefore, PsP can be developed as a suitable therapeutic option for treating patients with dyslipidemia, because PsP is a natural molecule which do not induce significant side effects [6]. Although $\beta$-glucan is generally considered safe, there is some concern that it may lower blood sugar. Therefore, people with hypoglycemia or anyone taking medications to reduce blood sugar should consult a physician before using $\beta$-glucan [7]. Furthermore, gastrointestinal side effects such as bloating, flatulence, and abdominal cramping have been reported. There are studies that indicate tolerance of $\beta$-glucan in doses up to 10 grams [8]. It is known that average age of patients in PsP group is 61.69 years old and in placebo groups is 64.15 years old.
Table 1. Characteristic of Respondents Based on Age

\begin{tabular}{lc}
\hline \multicolumn{1}{c}{ Parameter } & $\begin{array}{c}\text { Average Age (Year) } \\
\text { Mean } \pm \text { SD }\end{array}$ \\
\hline PsP Group & $61.69 \pm 9.578$ \\
\hline Placebo Group & $64.15 \pm 9.625$ \\
\hline
\end{tabular}

Table 2. Normality Test Results

\begin{tabular}{lcl}
\hline \multicolumn{1}{c}{ Group } & Mean \pm SD & $\begin{array}{c}\text { Significance } \\
\text { Value }\end{array}$ \\
\hline PsP Group & $207.23 \pm 23.920$ & 0.316 \\
\hline Placebo Group & $224.77 \pm 19.502$ & 0.302 \\
\hline
\end{tabular}

Based on the normality test result using Shapiro-Wiik test, derived significance value of PsP group is 0.316 while Placebo group's significance value is 0.302 . As a significance value which is $>0.05$ indicates normally distributed data, thus the data can be analyzed by using Paired T-test.

Table 3. Alteration of Total Cholesterol Level of Each Groups between Pre-test and Post-test

\begin{tabular}{llcc}
\hline \multicolumn{2}{c}{ Group } & Mean \pm SD & $\begin{array}{c}\text { Significance } \\
\text { Value }\end{array}$ \\
\hline PsP & Pre-test & $219.38 \pm 16.949$ & 0 \\
\cline { 2 - 3 } Group & Post-test & $195.08 \pm 24.181$ & 0.001 \\
\hline $\begin{array}{l}\text { Placebo } \\
\text { Group }\end{array}$ & Pre-test & $220.62 \pm 12.784$ & 0 \\
\cline { 2 - 3 } & Post-test & $228.92 \pm 24.332$ & 0.099 \\
\hline
\end{tabular}

Average total cholesterol level of patients in PsP group is decreased by $24.3 \mathrm{mg} / \mathrm{dL}$ with significance value 0.001 . A significance value which is $<0.05$ means there was a significance decrease in the average total cholesterol level between the pre-test and post-test in the PsP group. Whereas in placebo group, there is elevation of total cholesterol level of $8.3 \mathrm{mg} / \mathrm{dL}$ with significance value of 0.999 . It indicates that there is no significance reduction of average total cholesterol level between the pre-test and post-test in placebo group.

Table 4. Total Cholesterol Level Difference Between Two Groups

\begin{tabular}{|c|c|c|}
\hline Group & Mean \pm SD & Significance Value \\
\hline PsP Group & $24.31 \pm 20.303$ & \multirow[b]{2}{*}{0.000} \\
\hline $\begin{array}{l}\text { Placebo } \\
\text { Group }\end{array}$ & $-8.31 \pm 16.735$ & \\
\hline
\end{tabular}

The result of Independent T-test analysis shows that there is difference in average decreasing amount in total cholesterol level of PsP group and Placebo group. The average value of reduction in total cholesterol level of PsP group is greater than in Placebo group. so, it can be concluded that there is significant impact from PsP in reducing total cholesterol level in patients with ischaemic heart failure. 

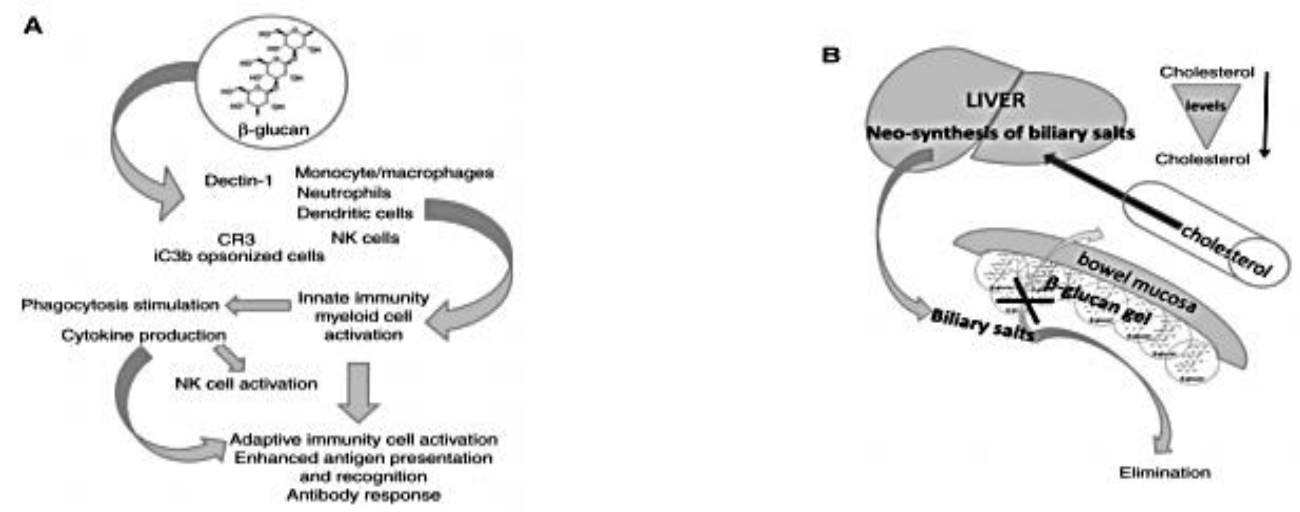

Figure 1. Simplified representasion of the effect of $\beta$-Glucan in immunity level and cholesterol balance. (A) $\beta$-Glucan interacts with a receptor which is expressed on the surface of innate immune cells and complements of $\mathrm{iC} 3 \mathrm{~b} / \mathrm{CR} 3$ cell, result immune stimulation involving innate and adaptive immunity. (B) It is hypothesized that $\beta$-Glucan as a fiber can form a gel on the surface of the intestinal mucosa. This activity can inhibit bile salt resorption and stimulate bile salt neo-synthesis in the liver. Increasing of bile salts can activate circulating cholesterol utilization, thereby reducing levels in the blood. NK: Natural Killer cell; CR3: complement receptor type [6].

\section{CONCLUSION}

There was a significant reduction in total cholesterol level of PsP-giving group and there was a significant difference in the reduction of total cholesterol level between PsP-giving group and Placebo-giving group. So it can be concluded that giving PsP capsules from mycelia Ganoderma lucidum extract affects reducing total cholesterol level in patients with ischemic heart failure at Saiful Anwar General Hospital in Malang. Further research is needed to investigate whether PsP can be used as an adjuvant therapy and as a statinalternative therapy for treating hypercholesterolemia.

\section{ACKNOWLEDGEMENT}

The authors are sending our thanks to the Ministry of Research and Technology of Indonesia which funded this research, Study Centre of Degerative Disease of Brawijaya University which have guided and facilitated this research, Sahabat Lingkungan Hidup Inc. that have provided research materials and all of the patients who are willing to participate in this research.

\section{REFERENCES}

1. Rampengan SH., 2014, Clinical Textbook of Cardiology. University of Indonesia: Jakarta.

2. Halimuddin and Sari IP., 2017, Total Cholesterol and Clinical Classification of New York Heart Association III and IV Congestive Heart Failure Patient. Idea Nursing Journal. 8(2): 43-49.

3. Sargowo D, Rahmah FN, Nugroho FW, Kamila PA, et al., 2019, The Role of
Polysaccharide Peptide (PsP) as an AntiInflammation Therapy and Vascular Endothelial Cell Protectors in Dyslipidemic Patient with or without Diabetes through IL1, TNF- $\alpha, \mathrm{Cr} \mathrm{Cr}$, EPC, CEC in STEMI and NSTEMI Patients. Int. Conf. Bioin. Nanomedicine from Natural Resources for Biomedical Research: 3rd Annual Scientific Meeting for Biomedical Sciences. DOI: 10.1063/1.5110019.

4. Wihastuti TA, Sargowo D, Widodo MA, Soeharto S, 2016, Evaluation Subchronic Toxic Effect of Polysaccharide Peptide (PsP) on Lipid and Hematologic Profile in Rattus norvegicus Strain Wistar, Bangladesh Journal of Medical Science. 15(3): 409-415.

5. Bintanah S, Muryati, 2010, The Relationship between Fat Consumption and Hypercholesterolemia in Outpatients in The Cardiovascular Polyclinic at The Kraton Regional General Hospital in Pekalongan, Journal of Public Health Indonesia. 6(1): 8590.

6. Sima P, Vannucci L, Vetvicka V., 2018, $\beta$ glucans and Cholesterol (Review). Int., J. Mol. Med. DOI: 10.3892/ijmm.2018/3411.

7. Kalra S, Mukherjee JJ, Venkataraman S, et al. Hypoglycemia: The Neglected Complication. Indian Journal of Endocrinology and Metabolism. September 2013. 17(5): 819-834. DOI: 10.4103/2230-8210.117219.

8. Charlton KE, Tapsell LC, Batterham MJ, O'Shea J, Thorner. Effect of 6 weeks Consumption of $\alpha$-glucan Rich Oat Products on Cholesterol Levels in Mildly Hypercholesterolemic Overweight Adults. British Journal of Nutrition. April 2012. 107: 1037-1047. DOI: $10.1017 / \mathrm{S} 0007114511003850$ 